\title{
Three new species of Lebiasina (Characiformes: Lebiasinidae) from the Brazilian Shield border at Serra do Cachimbo, Pará, Brazil
}

\author{
André L. Netto-Ferreira
}

Lebiasina marilynae n. sp., L. melanoguttata n. sp., and L. minuta n. sp. are described from the headwaters of the rio Curuá, in Serra do Cachimbo, Pará, Brazil, and represent the only members of the Lebiasininae in the Brazilian Shied, so far. A close relationship among these species is proposed based on: 1 ) the presence of a pair of foramina through which the ramus palatinus of the facial nerve passes, a modification unique in Lebiasinidae and apparently in the Characiformes, 2) the enlargement of the extrascapular bone, 3) the absence of the secondary stripe, and 4) the nearly equal length of caudal-fin lobes. Lebiasina marilynae additionally differs from all congeners in having the primary stripe extending from the tip of the snout to the distal border of the caudal-fin peduncle, the possession of two series of dark blotches parallel to the primary stripe, and a rounded dorsal surface of the mesethmoid. Lebiasina melanoguttata and Lebiasina minuta additionally differ from all congeners in the absence of the primary stripe and the caudal blotch, and the presence of three longitudinal series of dark blotches at the base of the scales of series 3-5. Lebiasina melanoguttata differs from Lebiasina minuta in the absence of a dark blotch at the base of the median rays of the dorsal fin, second infrapharyngobranchial bearing conical teeth, the reddish overall coloration of the eye and fins, and the dark blotches never coalescing (vs. dark dorsal-fin blotch present; the second infrapharyngobranchial being edentulous; dark, olive green eyes, and the yellowish overall color of body and fins; and the dark blotches of longitudinal series 3 and 4 coalescing where scales of adjacent longitudinal series overlap). The occurrence of species of the Lebiasininae on the Brazilian Shield is discussed, and the distribution pattern of the species described herein is compared to that of other endemic species of the Serra do Cachimbo, a highly biodiverse area isolated from the rest of the Amazon basin.

Lebiasina marilynae n. sp., L. melanoguttata n. sp. and L. minuta n. sp. são descritas das cabeceiras do rio Curuá, na Serra do Cachimbo, Pará, Brasil, e representam os únicos membros de Lebiasininae no escudo brasileiro, até o momento. Uma relação próxima entre estas espécies é proposta com base em: 1) presença de um par de forames por onde passa o ramo palatino do nervo facial, uma modificação única em Lebiasinidae e aparentemente em Characiformes, 2) a expansão do osso extra-escapular, 3) a ausência da faixa secundária, e 4) os lobos da nadadeira caudal com comprimento similar. Lebiasina marilynae difere ainda de seus congêneres pela faixa primária estendendo-se da ponta do focinho à porção distal do pedúnculo caudal, a presença de duas séries de manchas escuras paralelas à faixa primária, e a superfície dorsal do mesetmoide arredondada. Lebiasina melanoguttata e Lebiasina minuta também diferem de seus congêneres pela ausência da faixa primária e da mancha caudal, e pela presença de três séries longitudinais de manchas escuras na base das escamas das séries 3-5. Lebiasina melanoguttata difere de Lebiasina minuta pela ausência de uma mancha escura na base dos raios médios da nadadeira dorsal, presença de dentes cônicos no segundo infra-faringobranquial, a coloração avermelhada dos olhos e nadadeiras e pelas manchas escuras não coalescendo (vs. mancha escura presente na nadadeira dorsal; o segundo infrafaringobranquial sendo edêntulo; olhos escuros em tom oliváceo e coloração amarelada do corpo e nadadeiras; e as manchas escuras nas escamas das séries longitudinais 3 e 4 coalescendo no ponto onde escamas longitudinais adjacentes se sobrepõem). A ocorrência de espécies de Lebiasininae no escudo brasileiro é discutida e o padrão de distribuição das espécies descritas é comparado com o de outras espécies endêmicas da Serra do Cachimbo, uma área de alta biodiversidade isolada do restante da bacia amazônica.

Key words: Endemism, Lebiasininae, Neotropical, Ostariophysi, Systematics.

\section{Introduction}

The characiform family Lebiasinidae is endemic to the Neotropics and includes small sized freshwater fishes ranging from $15 \mathrm{~mm}$ SL to $200 \mathrm{~mm}$ SL (Weitzman \& Weitzman, 2003). Within the family, the subfamily Lebiasininae currently includes 23 nominal species, distributed in two genera, Lebiasina and Piabucina. Lebiasinins are usually found in the upper courses of streams with rocky or sandy bottoms and well oxygenated high waters in the rio Amazonas, río Orinoco and coastal drainages on the Atlantic and Pacific slopes of Colombia, Costa Rica, Ecuador, Guyana, Panama, 
Peru, and Venezuela. Lebiasina intermedia would be an exception to this distribution pattern, as its type locality was assigned by Meinken (1936) as "Mittlerer Amazonas bei Santarem" (Middle Amazon, near Santarém). Based on the general distribution pattern for the subfamily, though, most authors agree that this locality is likely to be wrong (Géry, 1977; Weitzman \& Weitzman, 2003; Eschmeyer \& Fricke, 2012).

Netto-Ferreira et al. (2011) described Lebiasina yepezi from the upper courses of the rio Negro, rio Branco and río Orinoco, and three new species of the Lebiasininae from headwaters of the rio Curuá (rio Xingu basin) are described herein. Both contributions provide evidence that the distribution of the subfamily in the Amazon basin is wider than previously noted, possibly due to lack of sampling in the headwaters of these tributaries of the Rio Amazonas. The Curuá drains from the Serra do Cachimbo, Pará, the highest portion of the Brazilian Shield. That region has a highly endemic fish fauna (Goulding et al., 2003), from where several species with restricted distributions were described (Travassos, 1960, 1964; Lima \& Birindelli, 2006; Birindelli \& Britski, 2009; Birindelli et al., 2009; Sousa et al., 2010; Netto-Ferreira \& Vari, 2011). Lebiasina and Piabucina are currently diagnosed by ambiguous characters, and several authors question the validity of Piabucina (e.g., Eigenmann \& Allen, 1942; Machado-Allison, 1974; Géry \& Zarske, 2002; Netto-Ferreira et al., 2011). The new species described herein are, therefore, assigned to Lebiasina. The relationships of the new species among the Lebiasininae are also discussed.

\section{Material and Methods}

Counts and measurements follow Fink \& Weitzman (1974) and Menezes \& Weitzman (1990). All measurements were made point-to-point on the left side of the specimens whenever possible using dial calipers with a precision of $0.1 \mathrm{~mm}$. Standard length is presented in mm, all other measurements are presented as proportions of standard length (SL), except for subunits of head, which are presented as proportions of head length (HL). Meristic data are given in the description, followed by the frequency of each count in parenthesis and an asterisk indicating values for the holotype. Counts of teeth, vertebrae, supraneurals, and procurrent caudal-fin rays were taken only from cleared and double-stained paratypes (cs), prepared according to Taylor \& van Dyke (1985), or radiographed specimens. Vertebrae of the Weberian apparatus were included as four elements in the precaudal counts, and the fused PU1+U1 of the caudal region is counted as a single element. Pattern of circuli and radii was observed on scales sampled from the region between the lateral line series and the insertion of the dorsal fin. Color pattern nomenclature follows Weitzman (1966). Nerve nomenclature follows Freihofer (1978). Institutional abbreviations are: Museu de Zoologia da Universidade de São Paulo (MZUSP), Academy of Natural Sciences of Philadelphia (ANSP), Colección Carlos A. Ardila Rodríguez (CAR), and Museo de Historia Natural de la Universidad Nacional Mayor de San
Marcos (MUSM). Specimens examined in the present study are the same as listed in Netto-Ferreira et al. (2011), with further additions indicated along the text.

\section{Lebiasina marilynae, new species Fig. 1}

Holotype. MZUSP 101375, 88.8 mm SL, Brazil, Pará, Altamira, rio Xingu drainage, unnamed tributary of rio Curuá, rio Iriri basin, near BR-163 road, 0849’12”S 5458’11”W, 11 Jan 2009, A. L. NettoFerreira, J. L. O. Birindelli, L. M. Sousa \& P. Hollanda-Carvalho.

Paratypes. Brazil, Pará, Altamira, MZUSP 99607, 3, 31.6-33.7 mm SL, rio Xingu drainage, unnamed tributary of rio Curuá, rio Iriri basin, near BR-163 road, 0849’12”S 5458’11”W, 29 Oct 2007, J. L. O. Birindelli, L. M. Sousa, A. L. Netto-Ferreira, M. H. Sabaj Pérez \& N. K. Lujan; MZUSP 99608, 1, 31.8 mm SL cs, rio Xingu drainage, unnamed tributary of rio Curuá, rio Iriri basin, near BR-163 road, 0849’12”S 5458’11”W, 29 Oct 2007 J. L. O. Birindelli, L. M. Sousa, A. L. Netto-Ferreira, M. H. Sabaj Pérez \& N. K. Lujan.

Diagnosis. Lebiasina marilynae is distinguished from all lebiasinins by its color pattern consisting of a slightly concave primary stripe, extending from the tip of the snout to the distal border of the caudal peduncle, a series of approximately 14 small blotches running nearly parallel to the primary stripe along the ventrally adjacent longitudinal series of scales and converging towards the stripe near the anal fin origin, and the lack of a secondary stripe. The new species further differs from its congeners by the presence of a pair of foramina on the ventral surface of the vomer through which the ramus palatinus of the facial nerve passes (Fig. 2a), the round dorsal surface of the mesethmoid (Fig. 3a), and the absence of an adipose fin (vs. vomer lacking a pair of foramina, ramus palatinus of the facial nerve passing lateral to the vomer - Fig. 2b; and a T-shaped dorsal surface of the mesethmoid - Fig. 3b).

Description. Morphometric data of the holotype and paratypes is presented in Table 1. Lateral view of holotype (preserved and live), and a fresh juvenile paratype in Fig. 1 (a, b, and c, respectively). Body cylindrical, elongate. Greatest body depth located anterior to dorsal-fin origin between pectoral and pelvic fins. Dorsal profile of head convex from tip of upper lip to dorsal-fin origin, straight from latter point to base of dorsal fin, and concave from that point to anteriormost dorsal caudalfin procurrent ray. Ventral profile of head and trunk distinctly convex from tip of lower lip to pelvic-fin origin, concave between origins of pelvic and anal fins. Anal-fin base profile slightly concave to nearly straight, from anal-fin terminus to origin of anteriormost ventral caudal-fin procurrent ray.

Mouth sub-superior. Premaxillary with single row of 9(1) tricuspid teeth. Maxillary with 5(1) tricuspid or conic teeth. Anteriormost tooth usually largest. Posterior terminus of maxilla reaching slightly beyond anterior margin of orbit. Dentary with two series of teeth; outer series with 12(1) pedunculate tricuspid teeth with central cusp distinctly longer than ones along margins, decreasing gradually in size 
posteriorly; inner series with several minute conical teeth extending from symphysis to coronoid process. Branchiostegal rays 4(5); three rays articulating with anterior ceratohyal and one with posterior ceratohyal.

Scales cycloid, circuli restricted to border of scales, several radii converging to center of scale and strongly anastomosed in center and forming several cells. Lateral line series with $25(2)$ or $26^{*}(3)$ scales, of which only $6 *(5)$ are perforated. Longitudinal rows of scales between dorsal and pelvic fins $7 *(5)$. Predorsal scales $11^{*}(3)$ or $12(2)$. First longitudinal row of scales usually reaching vertical through dorsal-fin terminus, but sometimes extending beyond that point by one or two scales. Circumpeduncular scales 12(5).

Pectoral-fin rays i,11(1) or 12*(4). Tip of longest pectoralfin ray falling far short of vertical through pelvic-fin insertion. Pelvic-fin rays i,7*(5). Supraneurals $8(1)$, anterior to neural spine of centra 6 to 13(1). Dorsal-fin rays iii,8(1) or ii,8*(4). First dorsalfin pterygiophore inserting behind neural spine of centrum $13^{*}(4)$. Distal margin of extended dorsal fin rounded. Dorsalfin origin located distinctly closer to caudal-fin origin than to tip of snout. Base of last dorsal-fin ray situated distinctly anterior to vertical through anal-fin origin. Anal-fin rays iii,8*(5), with

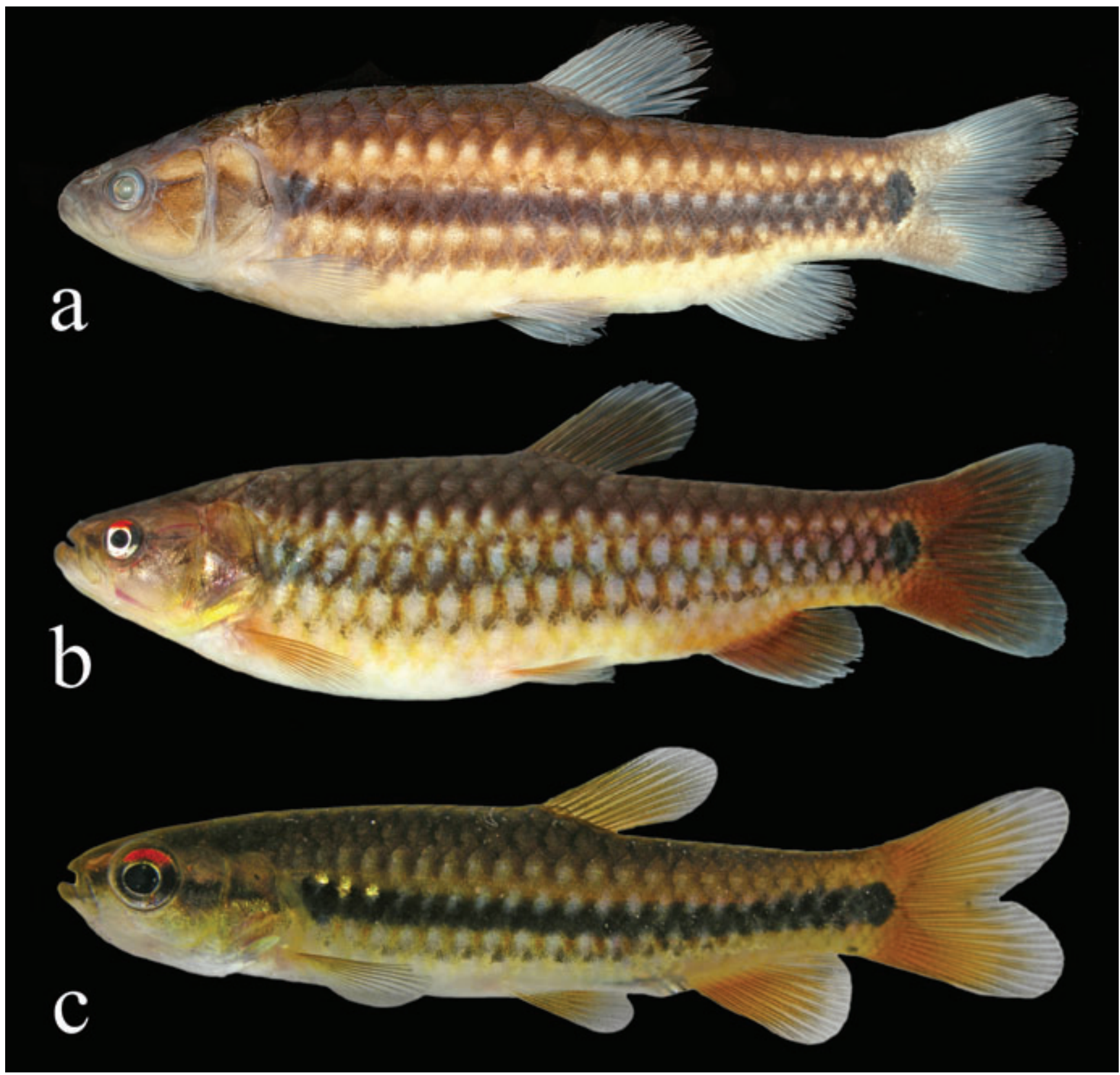

Fig. 1. Lebiasina marilynae: a) preserved, b) fresh holotype, MZUSP 101375, 88.8 mm SL, Altamira, Pará, Brazil; c) fresh juvenile paratype, MZUSP 99607, 32.6 mm SL, Altamira, Pará, Brazil. 
Table 1. Morphometric data of Lebiasina marilynae. $\mathrm{n}=$ number of specimens; SD = Standard Deviation.

\begin{tabular}{lccccc}
\hline & Holotype & $\mathrm{n}$ & Range & Mean & SD \\
\hline Standard length & 88.8 & 5 & $31.6-88.8$ & 43.7 & - \\
& Percentage of SL & & & & \\
Depth at dorsal-fin origin & 27.1 & 5 & $21.9-27.1$ & 24.1 & 1.9 \\
Snout to anal-fin origin & 78.1 & 5 & $75.9-78.1$ & 77.1 & 0.8 \\
Snout to pelvic-fin origin & 53.5 & 5 & $52.4-55.7$ & 53.7 & 1.2 \\
Snout to dorsal-fin origin & 58.0 & 5 & $57.1-58.0$ & 57.6 & 0.4 \\
Dorsal-fin origin to caudal-fin base & 45.9 & 5 & $42.6-45.9$ & 43.9 & 1.3 \\
Dorsal-fin length & 22.7 & 5 & $22.0-24.5$ & 23.3 & 1.0 \\
Dorsal-fin base & 11.1 & 5 & $8.5-11.1$ & 9.4 & 1.1 \\
Caudal-peduncle length & 14.6 & 5 & $13.4-14.8$ & 14.0 & 0.6 \\
Caudal-peduncle depth & 14.0 & 5 & $11.8-14.0$ & 12.4 & 0.9 \\
Anal-fin length & 19.7 & 5 & $19.7-21.2$ & 20.5 & 0.6 \\
Anal-fin base & 11.1 & 5 & $9.6-11.1$ & 10.2 & 0.6 \\
Pelvic- to anal-fin origin & 25.2 & 5 & $23.2-25.2$ & 23.8 & 0.8 \\
Pelvic-fin length & 14.4 & 5 & $14.4-17.6$ & 16.3 & 1.2 \\
Pectoral- to pelvic-fin origin & 29.4 & 5 & $26.4-29.4$ & 27.7 & 1.2 \\
Pectoral-fin length & 17.7 & 5 & $17.7-20.6$ & 19.1 & 1.2 \\
Snout to pectoral-fin origin & 25.2 & 5 & $25.2-28.1$ & 26.6 & 1.2 \\
Bony head length & 28.1 & 5 & $27.6-28.9$ & 28.2 & 0.5 \\
& 34.6 & & & & \\
Head width & Percentage of HL & & & & \\
Horizontal eye diameter & 52.4 & 5 & $47.8-52.4$ & 50.0 & 1.9 \\
Distance snout tip to eye & 19.2 & 5 & $19.2-31.1$ & 28.5 & 5.2 \\
Interorbital distance & 27.7 & 5 & $23.6-27.7$ & 25.8 & 1.5 \\
Length of lower jaw & 33.6 & 5 & $29.0-33.6$ & 31.1 & 1.8 \\
Length of upper jaw & 43.6 & 5 & $37.9-43.6$ & 39.8 & 2.2 \\
\hline & 34.1 & 5 & $25.5-34.1$ & 29.1 & 3.2 \\
\hline & & & &
\end{tabular}

last ray adnate. Distal margin of extended anal fin rounded. First anal-fin pterygiophore inserted posterior to haemal arch of centrum 22(4). Adipose fin absent. Caudal fin furcate with upper lobe slightly longer than lower lobe; both lobes rounded. Principal caudal-fin rays ii,8/i,8(1) or i,9/i,8*(4). Dorsal caudalfin procurrent rays 8(1), 9(1) or 10(2); ventral caudal-fin procurrent rays 7(2) or 8(2). Precaudal vertebrae 21(3) or 22(1); caudal vertebrae $14(1)$ or $15^{*}(3)$.
Color in alcohol. Ground coloration light yellowish. Head densely darkly pigmented from upper lip to origin of scales on the mid-posterior portion of parietals. Dark brown pigmentation extending from that point to caudal-fin insertion, over mid-dorsal series of scales and immediately bordering scale rows. Infraorbitals and opercular series largely covered with small chromatophores, with densely pigmented areas covered by primary stripe. Lower lip densely darkly pigmented. Ventral portion of head largely unpigmented except for patch of chromatophores posterior to dentary symphisis. Opercular membrane with small scattered chromatophores.

Body dark dorsally, becoming lighter ventrally from third longitudinal series of scales. Abdominal area yellowish and lacking distinct pigmentation between isthmus and anal-fin origin. Primary stripe extending from tips of upper and lower lips, passing through maxilla, antorbital, infraorbitals one, two, four, and five, eyes and opercle, interrupted from that point to humeral area and then extending over scales of longitudinal series 4 and 5 . Primary stripe becomes irregular with zigzag aspect at vertical through terminus of dorsal fin, and terminates at the caudal blotch. Dark spots present at base of scales of sixth longitudinal series, forming longitudinal series of around 14 dark spots converging towards primary stripe at vertical through first anal-fin branched ray. Abdominal region light yellow, with minute dark chromatophores. Conspicuous humeral blotch present. Dark pigmentation present along rays and intervening membranes of all fins.

Color in life. Same as in alcohol, except for dorsal portion of eyes red; fins orange; ventral portion of head yellowish; posterior border of scales on third to sixth longitudinal series greenish; scales 4 to 6 of lateral line system with intense

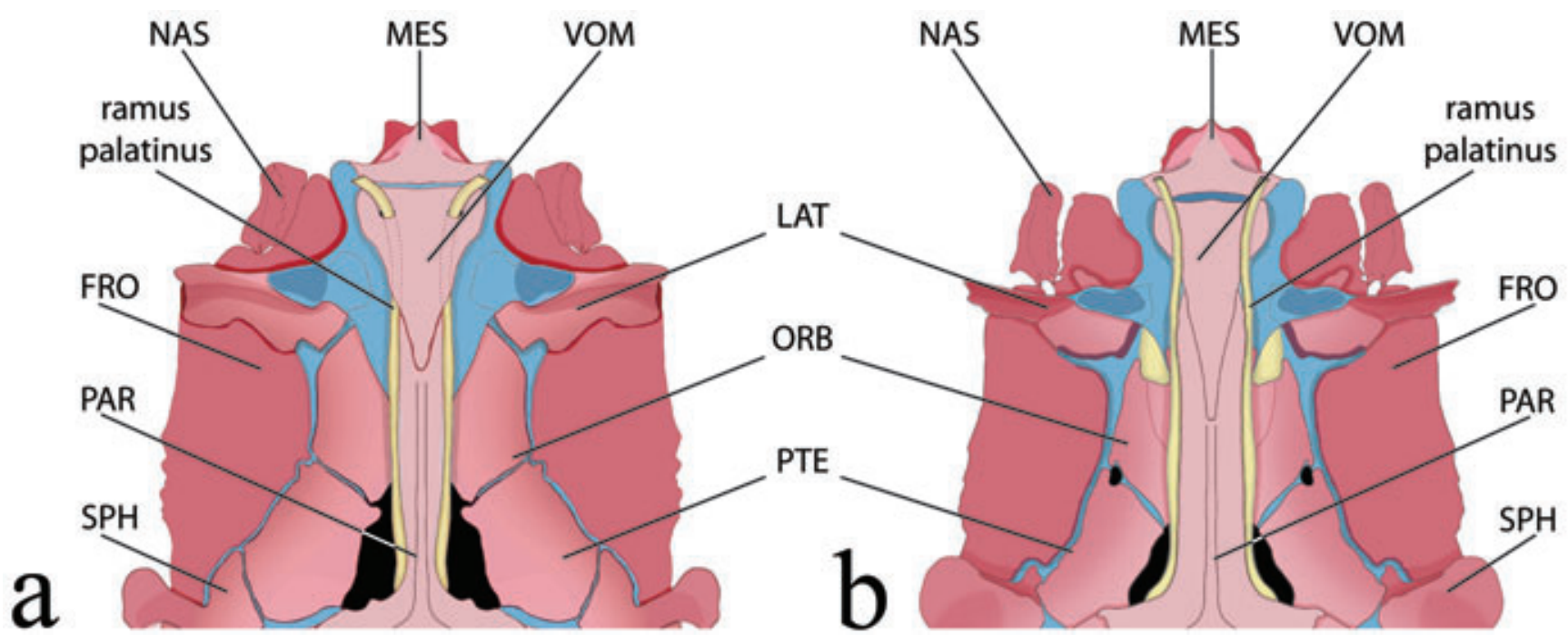

Fig. 2. Ventral view of medioanterior portion of the neurocranium of: a) Lebiasina melanoguttata, MZUSP 99610, paratype, 89.4 mm SL, Altamira, Pará, Brazil; b) Lebiasina ortegai CAR145, 94.5 mm SL, Alcalá, Valle del Cauca, Colombia. FRO - frontal; LAT - lateral ethmoid; MES - mesethmoid; NAS - nasal; ORB - orbitoshpenoid; PAR - parasphenoid; PTE - pterosphenoid; SPH - sphenotic; VOM - vomer. 
guanine deposition giving metallic coloration. When specimens are submitted to stress primary stripe chromatophores seem to contract (Fig. 1b).

Sexual dimorphism. All known specimens of Lebiasina marilynae are juveniles and an adult female, lacking secondary sexual characters.

Distribution. Lebiasina marilynae is known, until now, from a single collection site in the rio Curuá, rio Xingu basin (Fig. 4).

Etymology. The specific epithet is in honor to Marilyn J. Weitzman, who devoted her career to the study of fishes of the families Lebiasinidae and Characidae. A noun.

\section{Lebiasina melanoguttata, new species} Fig. 5

Lebiasina sp. - Sabaj Pérez, 2009: 40 [trip report]; Birindelli et al., 2009: 14 [trip report].

Holotype. MZUSP 99609, 85.9 mm SL, Brazil, Pará, Altamira, rio Xingu drainage, unnamed tributary of rio Curuá, rio Iriri basin, near BR-163, 0849’12”S 5458'11”W, 29 Oct 2007, A. L. NettoFerreira, L. M. Sousa, J. L. O. Birindelli, M. H. Sabaj Pérez \& N. K. Lujan.

Paratypes. Brazil, Pará, Altamira: ANSP 192061, 5, 77.2-81.3 mm SL, MZUSP 99610, 22, 41.73-93.53 mm SL; 3 cs, 72.5189.41, same data as holotype; MZUSP 99611, 12, 6.17-32.26 $\mathrm{mm}$ SL, rio Xingu drainage, unnamed tributary of rio Curuá, rio Iriri basin, near BR-163 road, 0847’03”S 5458'29”W, 29 Oct 2007, A. L. Netto-Ferreira, L. M. Sousa, J. L. O. Birindelli, M. H. Sabaj Pérez \& N. K. Lujan; MZUSP 101382, 9, 43.1-110.2 $\mathrm{mm} \mathrm{SL}$, rio Xingu drainage, unnamed tributary of rio Curuá, rio Iriri basin, near BR-163 road, 0849’12”S 5458’11”W, 22 Jan 2009, A. L. Netto-Ferreira, L. M. Sousa, J. L. O. Birindelli \& P. Hollanda-Carvalho.
Diagnosis. Lebiasina melanoguttata is readily distinguished from all lebiasinins (except for $L$. minuta) by the absence of the primary and secondary stripes, and the caudal blotch; the presence of three longitudinal series of dark blotches at the base of the scales; the pair of foramina on the vomer through which the ramus palatinus of the facial nerve runs (Fig. 2a); the large laminar extrascapular bone in contact with the fifth infraorbital, and overlaying the anterodorsal portion of the opercle; and nearly equal caudal-fin lobes. Lebiasina melanoguttata differs from Lebiasina minuta by the absence of a dark blotch at the base of the median rays of the dorsalfin, the presence of conical teeth on the second infrapharyngobranchial, the reddish overall coloration of the eye and fins, and the dark blotches of longitudinal series 3 and 4 which never coalesce (vs. a dark blotch present at the base of the median rays of the dorsal-fin; the second infrapharyngobranchial being edentulous; a yellowish overall color of body, and the dark, olive green eyes; and the dark blotches of longitudinal series 3 and 4 coalescing where scales of adjacent longitudinal series overlap).

Description. Morphometric data of holotype and paratypes presented in Table 2. Lateral view of holotype and live specimen shown in Figs 5a and 5c, respectively. Body cylindrical, elongate. Dorsal profile of head convex from tip of upper lip to vertical through anterior nostrils; nearly straight from latter point to base of scales covering posterior half of parietals. Body profile nearly straight to base of dorsal fin, and distinctly concave from that point to origin of anteriormost dorsal procurrent ray of caudal fin. Ventral profile of head and trunk distinctly convex from lower lip to pelvic-fin origin; nearly straight from that point to anal-fin origin; convex along anal-fin base, and nearly straight from anal-fin terminus to origin of anteriormost ventral procurrent ray of caudal fin.

Mouth sub-superior. Premaxillary with single row of 11(2) or 13(1) tricuspid teeth. Maxillary with 4(3) tricuspid teeth.

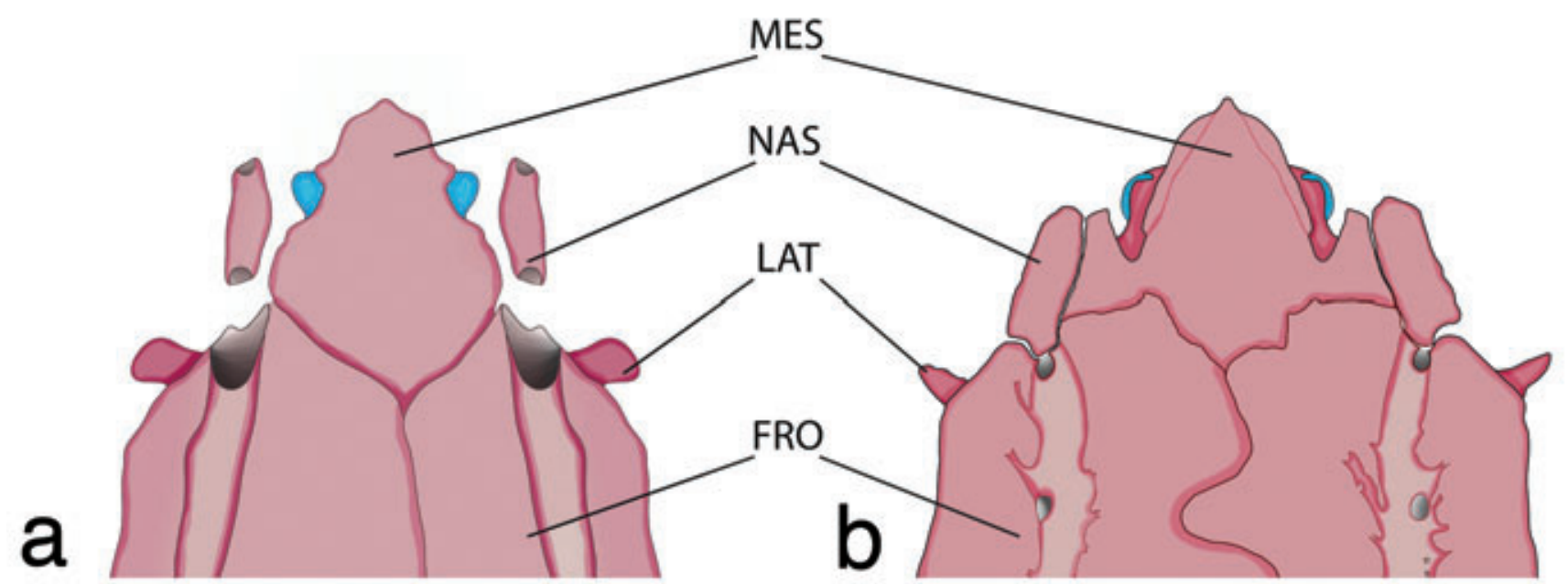

Fig. 3. Dorsal view of the mesethmoid of: a) Lebiasina marilynae, MZUSP 99608, paratype, 31.8 mm SL, Altamira, Pará, Brazil; b) Lebiasina elongata, MUSM 21356, 73.1 mm SL, Cenepa, Amazonas, Peru. FRO - frontal; LAT - lateral ethmoid; MES mesethmoid; NAS - nasal. 


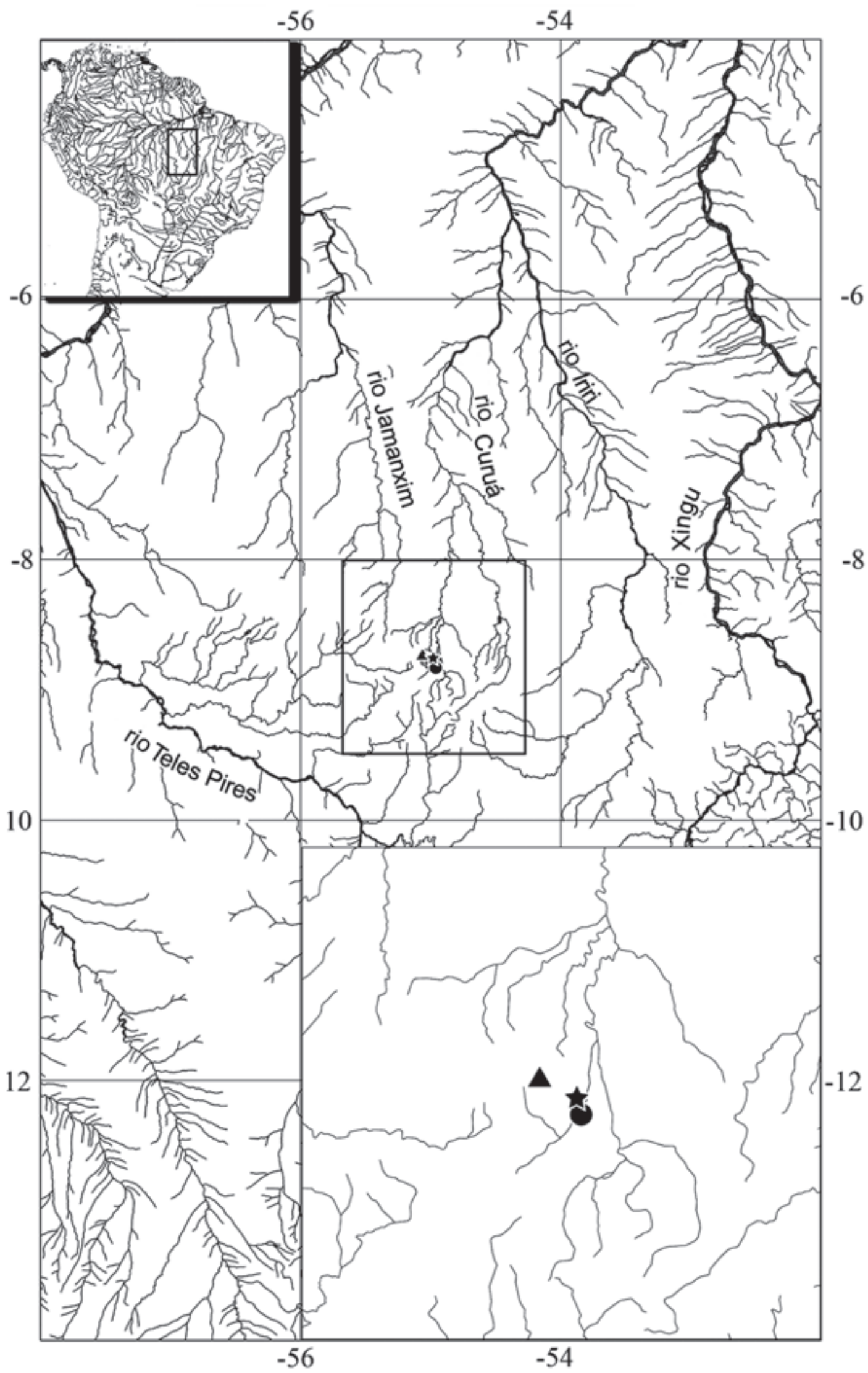

Fig. 4. Map of rio Tapajós basin and adjoining areas, showing the distribution of Lebiasina marilynae n. sp. (star); Lebiasina melanoguttata n. sp. (circle); Lebiasina minuta n. sp. (triangle). Symbols may represent more than one collection event. 
Anteriormost tooth usually largest. Posterior terminus of maxilla reaching to, or extending slightly beyond, anterior margin of orbit. Dentary with two series of teeth; outer series with 13(1), 14(1) or 15(1) pedunculate tricuspid teeth with central cusp distinctly longer than lateral marginal cusps, teeth gradually decreasing in size posteriorly. Inner tooth series with several minute conical teeth extending from symphysis to coronoid process. Branchiostegal rays 4(3); three rays originating from anterior ceratohyal and one from posterior ceratohyal.
Scales cycloid, circuli restricted to border of scales, several radii (around 32) converging to center of scale and strongly anastomosed in center and forming several cells. Lateral line series with 26(1), 27(12), or 28*(8) scales, of which only 4(1), $5^{*}(6)$, or $6(2)$ are perforated. Longitudinal rows of scales between dorsal and pelvic fins $7 *(21)$. Predorsal scales 12(4), $13 *(13)$ or $14(4)$. Circumpeduncular scales $12 *(21)$.

Pectoral-fin rays i,12(1), 13(8), 14*(17), or 15(4). Tip of longest pectoral-fin ray falling far short of vertical through pelvic-fin insertion. Pelvic-fin rays i,7*(21). Supraneurals $11(3)$, anterior to
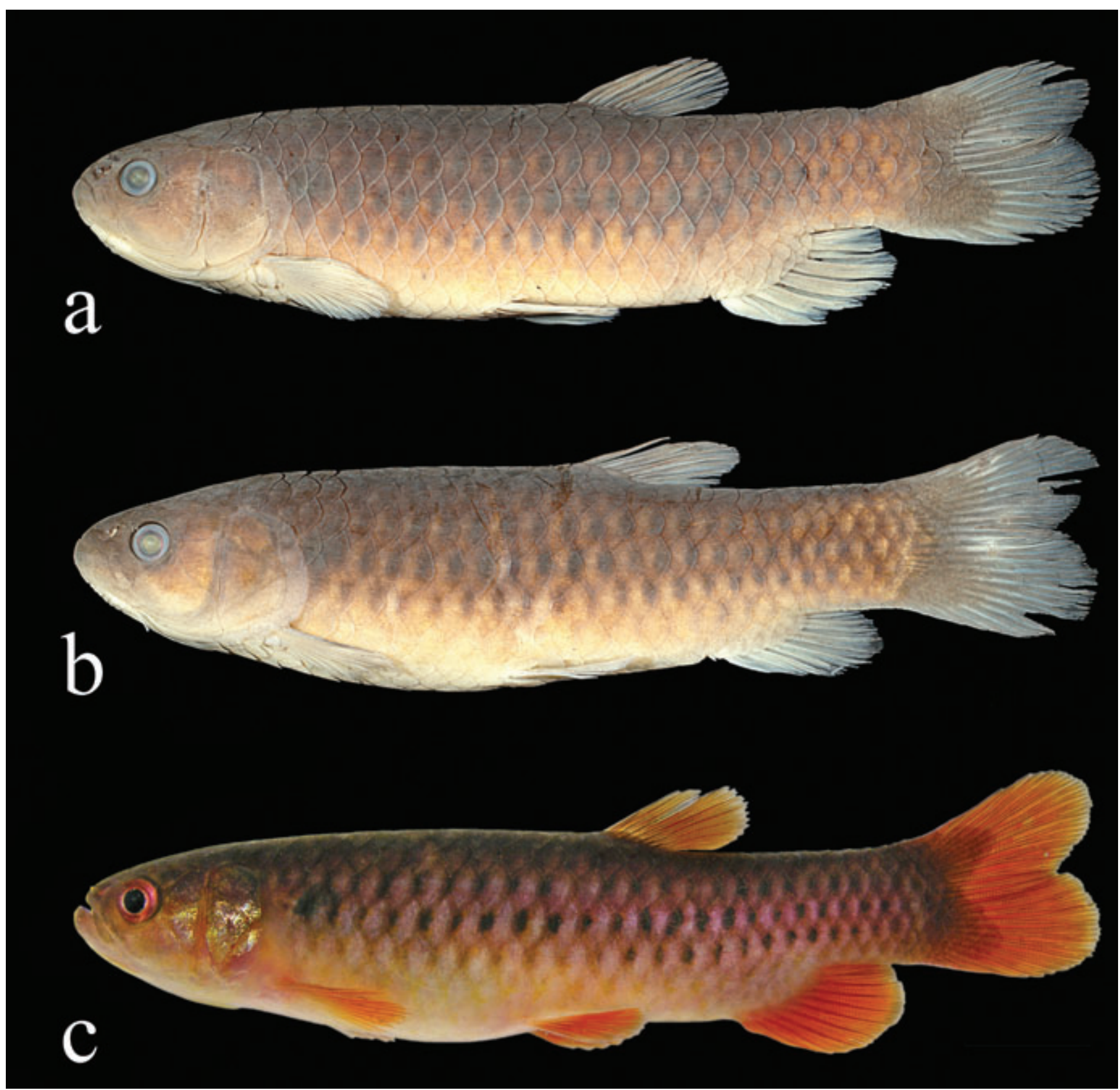

Fig. 5. Lebiasina melanoguttata: a) preserved holotype, MZUSP 99609, 85.9 mm SL, Altamira, Pará, Brazil; b) female paratype, MZUSP 99610, 93.5 mm SL, Altamira,Pará, Brazil; c) fresh paratype, MZUSP 99611, 62.1 mm SL, Altamira, Pará, Brazil, showing live color pattern. 
Table 2. Morphometric data of Lebiasina melanoguttata. $\mathrm{n}=$ number of specimens; SD = Standard Deviation

\begin{tabular}{lccccc}
\hline & Holotype & $\mathrm{n}$ & Range & Mean & SD \\
\hline Standard length & 85.9 & 23 & $68.7-93.5$ & 77.1 & - \\
& Percentage of SL & & & & \\
Depth at dorsal-fin origin & 24.4 & 21 & $22.5-25.0$ & 23.8 & 0.7 \\
Snout to anal-fin origin & 78.8 & 21 & $75.3-79.7$ & 77.5 & 1.1 \\
Snout to pelvic-fin origin & 52.6 & 20 & $50.7-55.6$ & 52.5 & 1.2 \\
Snout to dorsal-fin origin & 60.7 & 21 & $59.5-63.2$ & 60.7 & 1.0 \\
Dorsal-fin origin to caudal-fin base & 43.0 & 21 & $39.1-43.0$ & 41.2 & 0.9 \\
Dorsal-fin length & 19.4 & 21 & $19.0-21.4$ & 20.0 & 0.6 \\
Dorsal-fin base & 7.5 & 21 & $7.5-9.1$ & 8.4 & 0.4 \\
Caudal-peduncle length & 15.3 & 21 & $14.0-16.6$ & 15.4 & 0.7 \\
Caudal-peduncle depth & 14.1 & 21 & $13.1-15.8$ & 14.1 & 0.6 \\
Anal-fin length & 21.8 & 21 & $18.4-24.3$ & 21.3 & 1.9 \\
Anal-fin base & 11.3 & 21 & $8.5-12.2$ & 10.7 & 1.2 \\
Pelvic- to anal-fin origin & 27.7 & 20 & $24.5-27.7$ & 25.7 & 0.9 \\
Pelvic-fin length & 14.6 & 20 & $13.1-15.7$ & 14.7 & 0.7 \\
Pectoral- to pelvic-fin origin & 31.2 & 20 & $27.5-32.7$ & 29.6 & 1.4 \\
Pectoral-fin length & 17.5 & 21 & $16.6-18.3$ & 17.6 & 0.4 \\
Snout to pectoral-fin origin & 22.5 & 21 & $22.2-24.8$ & 23.5 & 0.7 \\
Bony head length & 23.8 & 21 & $23.5-25.4$ & 24.5 & 0.6 \\
& Percentage of HL & & & \\
Head width & 69.4 & 21 & $57.6-69.4$ & 62.9 & 3.0 \\
Horizontal eye diameter & 20.9 & 21 & $19.6-23.4$ & 21.7 & 0.9 \\
Distance snout tip to eye & 26.3 & 21 & $26.3-29.3$ & 27.5 & 1.0 \\
Interorbital distance & 41.6 & 21 & $38.0-42.7$ & 40.2 & 1.2 \\
Length of lower jaw & 38.0 & 21 & $37.2-42.1$ & 40.0 & 1.2 \\
Length of upper jaw & 34.0 & 21 & $32.3-36.7$ & 34.0 & 1.0 \\
\hline & & & & & \\
& & & &
\end{tabular}

neural spine of centra 5 to 15(3). Dorsal-fin rays ii,8*(21). First dorsal-fin pterygiophore inserting behind neural spine of centrum 15(3). Distal margin of extended dorsal fin rounded. Dorsal-fin origin distinctly closer to caudal-fin origin than to tip of snout. Base of last dorsal-fin ray located distinctly anterior to vertical through anal-fin origin. Anal-fin rays iii,8*(20) or iii,9(1), with last ray adnate. Distal margin of extended anal fin rounded. First anal-fin pterygiophore inserted posterior to haemal spine of centrum 22(3). Adipose fin absent. Caudal fin furcate with upper lobe slightly longer than lower lobe; both lobes rounded. Caudalfin principal rays ii,8/i,8*(11), i,9/i,8(8). Dorsal procurrent caudalfin rays 6(2) or 7(1); ventral procurrent caudal-fin rays 7(2) or 8(1). Precaudal vertebrae 21(3); caudal vertebrae 15(3).

Color in alcohol. Background color predominantly brown. Head densely pigmented from upper lip to first scales overlying portion of parietal. Dark brown pigmentation extending from that point to insertion of caudal fin, along mid-dorsal series of scales and immediately bordering scale rows. Maxilla, circumorbital bones and opercular series dark, becoming lighter ventrally. Lower lip densely pigmented. Ventral portion of head with scarce pigmentation. Opercular membrane with small scattered chromatophores.

Trunk dark dorsally, becoming lighter ventrally from third longitudinal series of scales. Abdominal region yellowish, with minute dark chromatophores from isthmus to anal-fin origin. Humeral blotch rounded; more conspicuous in juvenile and smaller adult specimens but inconspicuous in large adults (60.0-65.0 mm SL) due to dark overall pigmentation of body. Primary and secondary longitudinal stripes absent. Three longitudinal series of dark blotches at base of scales of longitudinal series 3 to 5; dark blotches never coalescing.
Caudal blotch absent. Dark pigmentation present along rays and intervening membranes of all fins.

Color in life. Same as in alcohol, except for red eyes and fins; reddish ventral portion of head; and pearly coloration on scales of longitudinal series 3 to 6 posterior to dark blotches (Fig. 5c).

Sexual dimorphism. As in most lebiasinids, mature male specimens of Lebiasina melanoguttata possess several modifications in the anal fin including: longer and thicker anal-fin rays similar to the condition observed in Ctenolucius (Vari, 1995), some alestids (Zanata \& Vari, 2005) and Hoplerythrinus; anal-fin rays with thickened membranes, a condition also shared with Hoplerythrinus; very developed anal-fin rays erectors and depressors muscles, as also observed in Hoplerythrinus and the characid genera Attonitus and Bryconadenos (Vari \& Ortega, 2000; Weitzman et al., 2005); and breeding tubercles on the infraorbital bones, opercle and subopercle, lateral surface of pectoral- and pelvicfin rays, posterior border of scales on the sides of the body and caudal-fin rays. Among examined lebiasinids, breeding tubercles are also present in Nannostomus beckfordi, $N$. bifasciatus, $N$. limatus, $N$. marginatus, and $N$. nitidus, but in these species the tubercles are restricted to the anteroventral surface of the head, instead of distributed along the body.

Distribution. Lebiasina melanoguttata is known from two tributaries of the rio Curuá (rio Xingu basin) in Serra do Cachimbo (Fig. 4).

Etymology. The specific epithet melanoguttata (melan- = black; guttata $=$ dotted) is in reference to the longitudinal series of dark blotches present along the flanks of Lebiasina melanoguttata. An adjective.

\section{Lebiasina minuta, new species. Fig. 6}

Holotype. MZUSP 110693, 62.1 mm SL, Brazil, Pará, Altamira, rio Xingu drainage, rio Treze de Maio, rio Iriri basin, near BR-163, 0847’03”S 5458’29”W, 22 Jan 2009, A. L. Netto-Ferreira, J. L. O. Birindelli, L. M. Sousa, P. Hollanda-Carvalho.

Paratypes. Brazil, Pará, Altamira: ANSP 192062, 5, 58.2-62.5 mm SL, MZUSP 101423, 94, 14.8-68.4 mm SL; 2 cs 55.7-58.0 mm SL, same data as holotype; MZUSP 101412, 1, $54.0 \mathrm{~mm}$ SL, rio Xingu drainage, rio Treze de Maio, rio Iriri basin, near BR-163 road, upstream of dam, 0847’03”S 5458'29”W, 22 Jan 2009, A. L. Netto-Ferreira, J. L. O. Birindelli, L. M. Sousa \& P. Hollanda-Carvalho.

Diagnosis. Lebiasina minuta is readily distinguished from all lebiasinins (except for $L$. melanoguttata) by the absence of the primary and secondary stripes, as well as the caudal blotch; the presence of three longitudinal series of dark blotches at the base of the scales; the pair of foramina on the vomer through which the ramus palatinus of the facial nerve passes (Fig. 2a); the large laminar extrascapular bone in contact 

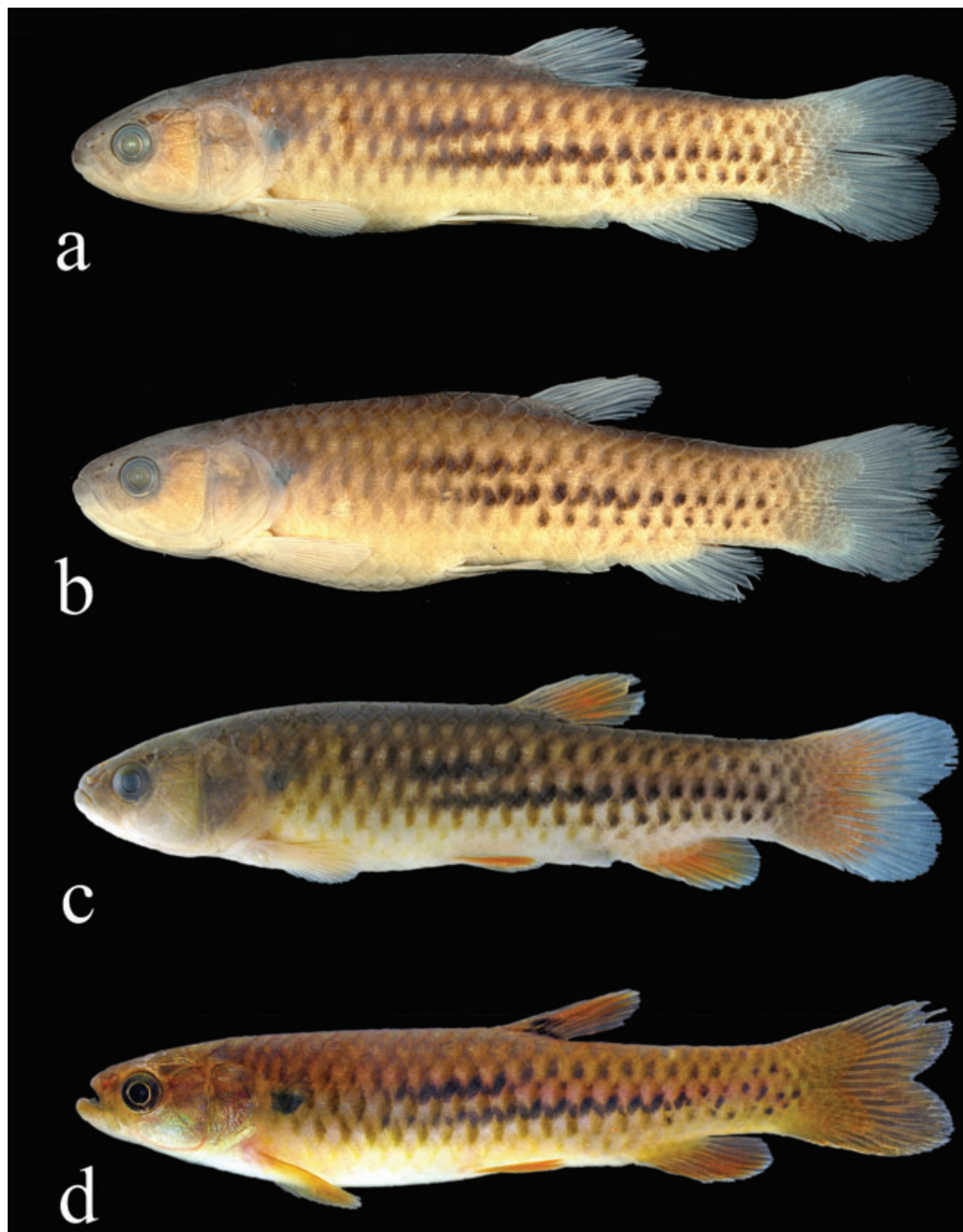

Fig. 6. Lebiasina minuta: a) male holotype, MZUSP 110693, $62.1 \mathrm{~mm}$ SL, Altamira, Pará, Brazil; b) female paratype, MZUSP 101412, 60.3 mm SL, Altamira, Pará, Brazil; c) fresh holotype, d) fresh paratype, MZUSP 101413, 54.0, mm SL, Altamira, Pará, Brazil, showing live color pattern. 
with the fifth infraorbital and overlaying the anterodorsal portion of the opercle; and the nearly equal caudal-fin lobes. Lebiasina minuta differs from $L$. melanoguttata in the presence of a dark blotch at the base of the middle dorsal-fin rays, the second infrapharyngobranchial being edentulous, the yellowish overall coloration of the body, the dark olive green eyes, and the dark blotches of longitudinal series 3 and 4 coalescing where scales of adjacent longitudinal series overlap (vs. dark blotch absent; second infrapharyngobranchial with conical teeth; the reddish overall color of body and eyes; and the dark blotches of longitudinal series not coalescing).

Description. Morphometric data of the holotype and paratypes presented in Table 3. Lateral view of holotype, preserved paratype, recently preserved holotype and live paratype in Fig. 6 (a, b, c, and d, respectively). Body cylindrical, elongate. Dorsal profile of head convex from tip of upper lip to vertical through anterior nostrils; nearly straight from latter point to base of scales covering posterior half of parietals. Body profile nearly straight from that point to base of dorsal fin, then distinctly concave to origin of anteriormost dorsal procurrent ray of caudal fin. Ventral profile of head and trunk distinctly convex from lower lip to pelvic-fin origin; nearly straight from that point to anal-fin origin; convex along anal-fin base, and nearly straight from anal-fin terminus to origin of anteriormost ventral procurrent ray of caudal fin.

Mouth sub-superior. Premaxillary with single row of 13(2) tricuspid teeth. Posterior terminus of maxilla reaching to, or extending slightly beyond, anterior margin of orbit. Maxillary with 5(2) tricuspid or conical teeth. Anteriormost tooth usually largest. Dentary with two series of teeth; outer series with 16(2) pedunculate tricuspid teeth with central cusp distinctly longer than marginal cusps, gradually decreasing in size posteriorly. Inner teeth series with several minute conical teeth extending from symphysis to coronoid process. Branchiostegal rays 4(2); three rays attaching to anterior ceratohyal and one to posterior ceratohyal.

Scales cycloid, circuli restricted to border of scales, several radii converging to center of scale and strongly anastomosed in center, and forming several cells. Lateral line with 25(5), $26 *(14)$ or $27(1)$ scales, of which only $5^{*}(20)$ are perforated. Longitudinal rows of scales between dorsal and pelvic fins $7 *(20)$. Predorsal scales $12(1), 13(6)$, or $14 *(11)$. Circumpeduncular scales $12 *(20)$.

Pectoral-fin rays i,11(6), 12*(8), 13(5), or 14(1). Tip of pectoral fin falling far short of pelvic-fin insertion. Pelvic-fin rays i, $7^{*}(21)$. Supraneurals $11(2)$, anterior to neural spine of centra 5 to 15(2). Dorsal-fin rays ii,8*(21). First dorsal-fin pterygiophore inserting behind neural spine of centrum 15(1) or 16(1). Distal margin of extended dorsal fin rounded. Dorsalfin origin distinctly closer to caudal-fin origin than to tip of snout. Base of last dorsal-fin ray located distinctly anterior to vertical through anal-fin origin. Anal-fin rays iii,8*(20) or iii,9(1), with last ray adnate. Distal border of extended anal fin rounded. First anal-fin pterygiophore inserted posterior to
Table 3. Morphometric data of Lebiasina minuta. $\mathrm{n}=$ number of specimens, $\mathrm{SD}=$ Standard Deviation.

\begin{tabular}{lccccc}
\hline & Holotype & $\mathrm{n}$ & Range & Mean & SD \\
\hline Standard length & 62.1 & 20 & $56.1-68.4$ & 61.2 & - \\
& 22.1 & 20 & $20.5-23.2$ & 21.9 & 0.8 \\
Depth at dorsal-fin origin & 75.4 & 20 & $73.9-77.9$ & 75.8 & 1.1 \\
Snout to anal-fin origin & 51.7 & 20 & $49.2-54.3$ & 52.3 & 1.4 \\
Snout to pelvic-fin origin & 61.0 & 20 & $58.7-62.6$ & 61.0 & 1.1 \\
Snout to dorsal-fin origin & 39.9 & 20 & $39.7-43.3$ & 41.2 & 1.0 \\
Dorsal-fin origin to caudal-fin base & 19.9 & 20 & $19.0-22.7$ & 20.1 & 1.0 \\
Dorsal-fin length & 8.9 & 20 & $7.8-10.0$ & 8.7 & 0.5 \\
Dorsal-fin base & 13.3 & 20 & $12.3-16.0$ & 13.9 & 0.9 \\
Caudal-peduncle length & 13.3 & 20 & $12.2-14.2$ & 13.2 & 0.4 \\
Caudal-peduncle depth & 19.9 & 19 & $19.9-22.6$ & 21.2 & 0.8 \\
Anal-fin length & 10.5 & 20 & $10.3-12.3$ & 11.2 & 0.6 \\
Anal-fin base & 25.2 & 20 & $22.7-25.5$ & 24.2 & 0.8 \\
Pelvic- to anal-fin origin & 14.2 & 20 & $13.4-15.0$ & 14.3 & 0.4 \\
Pelvic-fin length & 27.9 & 20 & $25.8-30.4$ & 28.1 & 1.0 \\
Pectoral- to pelvic-fin origin & 17.9 & 20 & $15.9-20.0$ & 17.6 & 0.9 \\
Pectoral-fin length & 24.5 & 20 & $22.1-25.5$ & 24.2 & 0.8 \\
Snout to pectoral-fin origin & 26.0 & 20 & $24.5-26.9$ & 26.0 & 0.6 \\
Bony head length & 62.5 & 20 & 53.9 & 57.9 & 2.4 \\
& 22.8 & 20 & 21.4 & 23.4 & 1.0 \\
Head width & 26.4 & 20 & 24.5 & 25.7 & 0.9 \\
Horizontal eye diameter & 37.3 & 20 & 32.8 & 34.9 & 1.1 \\
Distance snout tip to eye & 43.0 & 20 & 39.6 & 41.8 & 1.4 \\
Interorbital distance & 35.0 & 20 & 32.6 & 35.2 & 1.4 \\
Length of lower jaw & & & & & \\
Length of maxilla & & & & &
\end{tabular}

haemal arch of centrum 23(1) or 24(1). Adipose fin absent. Caudal fin furcate with upper lobe slightly longer than lower lobe; both lobes rounded. Caudal-fin principal rays ii,8/ii,7(3), ii,8/i,8*(12) or i,9/i,8(4). Dorsal caudal-fin procurrent rays 8(1) or 9(1); ventral caudal-fin procurrent rays 8(2). Precaudal vertebrae 22(1) or 23(1); caudal vertebrae 15(2).

Color in alcohol. Background color predominantly tan. Head densely pigmented from upper lip to origin of scales overlying portion of parietals. Dark brown pigmentation extending from that point to insertion of caudal fin, over mid-dorsal series of scales and immediately bordering scale rows. Maxilla, infraorbitals and opercular series becoming lighter ventrally. Lower lip darkly pigmented. Ventral portion of head with scarce pigmentation. Opercular membrane with small scattered chromatophores.

Trunk dark dorsally, becoming lighter ventrally from third longitudinal series of scales. Abdominal region light yellowish, with minute dark chromatophores from isthmus to anal-fin origin. Humeral blotch rounded, conspicuous in both juvenile and smaller adult specimens. Primary and secondary longitudinal stripes absent. Three longitudinal series of dark blotches at base of scales of longitudinal series 3 to 5; dark blotches of series 3 and 4 coalescing. Caudal blotch absent. Dark pigmentation present along rays and intervening membranes of all fins.

Color in life. Same as in alcohol, except for dark olive green eyes and yellowish fins; yellowish ventral portion of head; pearly coloration posterior to the dark blotches on longitudinal scale series 3 and 4 (Fig. 6d). 
Sexual dimorphism. As in most lebiasinids, male specimens of Lebiasina minuta demonstrate several modifications in the anal fin as described for L. melanoguttata. These modifications are less pronounced in $L$. minuta perhaps as a function of the small body size of this species.

Distribution. Lebiasina minuta is known from two tributaries of the rio Curuá (rio Xingu basin) in Serra do Cachimbo (Fig. 4).

Etymology. The specific epithet minuta (=small) is in reference to the small size of adult specimens of Lebiasina minuta. Despite the large sample size of this species, no specimen larger than $68.4 \mathrm{~mm}$ SL was collected. In addition, most specimens larger than $50 \mathrm{~mm}$ SL were mature. An adjective.

\section{Discussion}

The species described herein share a modification on the path of the ramus palatinus of the facial nerve along the ventral surface of the vomer not observed elsewhere in the Lebiasinidae and other examined members of the Characiformes. This unique condition, along with the enlargement of the extrascapular bone and the absence of the secondary stripe, a widely distributed feature in all other Lebiasininae, are strong evidence for a close relationship among Lebiasina marilynae, L. melanoguttata, and L. minuta. The shared color pattern of $L$. melanoguttata and $L$. minuta, also lacking the primary stripe and the caudal blotch, furthermore suggests that they are sister species.

The occurrence of species of Lebiasina in the Serra do Cachimbo region (rio Xingu basin) refutes the apparent restriction of the Lebiasininae to Andean and Guyana Shield drainages. Most species in the Lebiasininae have a short distribution range, and inhabit short stretches of river. The gap of more than $1500 \mathrm{~km}$ between the Serra do Cachimbo and the geographically closest region where lebiasinins are known to occur, the Gran Sabana (Venezuela), suggests that lebiasinins were more widely distributed in the past, and that multiple extinction events may have occurred in the intervening regions. If that is the case, then the three species described herein represent a relictual fauna of the Brazilian Shield border, and further sampling in the higher portions of the northern Brazilian Shield border and the Guyana Shield might yield additional unknown species of the Lebiasininae.

The combined distribution of the species described herein is similar to that of the group of species formed by Moenkhausia chlorophtalma, M. petymbuaba, and $M$. plumbea suggested by Sousa et al. (2010), which are endemic to the rio Treze de Maio, rio Curuá and rio Braço Norte respectively. Both cases not only corroborate the high endemicity of the fish fauna of that region suggested by Goulding et al. (2003), but also suggest an interesting case of allopatric speciation of phylogenetically close species occurring in a very constrained area. The Serra do Cachimbo is isolated from the rest of the Amazon drainage by a complex series of rapids and waterfalls, which can reach a height of up to $80 \mathrm{~m}$. This particular combination of topographic features results in a "closed" system not influenced by other river basins, where sister species can occur as close as distances of less than $8 \mathrm{~km}$. Other genera yet under study such as Apistogramma (at least two undescribed species), Harttia (five undescribed species and $H$. dissidens, a widely distributed species in the Tapajós basin), Leporinus ( $L$. guttatus, L. octomaculatus and L. gr. granti), Jupiaba (J. kurua, J. minor) and several other species of the Characidae, all endemic to the Serra do Cachimbo further highlight the Serra do Cachimbo as an isolated biodiversity rich area.

\section{Acknowledgements}

Thanks are due to Richard P. Vari (USNM) and Cristiano Moreira (UNIFESP) for comments and suggestions to the manuscript. Specimens of Lebiasina melanoguttata (MZUSP 99609, MZUSP 99610 and MZUSP 99611) and Lebiasina marilynae (MZUSP 99607 and MZUSP 99608) were collected during the PIPE expedition to Serra do Cachimbo, a joint collaboration of MZUSP, ANSP and AUM, funded by All Catfish Species Inventory (NSF DEB-0315963). The author is grateful to Mark Sabaj Pérez, Nathan K. Lujan, José L. Birindelli, Leandro M. Sousa and Pedro HollandaCarvalho for their help and assistance during the field expeditions. Pictures of live specimens were provided by Mark Sabaj Pérez (Fig. 1c; Fig. 5c) and José L. Birindelli (Fig. $5 b)$; photos of preserved specimens were taken by Eduardo Baena (MZUSP). The author was financially supported by FAPESP (2006/04161- 5, 2010/19088-7, and 2011/50282-7).

\section{Literature Cited}

Birindelli, J. L. O. \& H. A. Britski. 2009. New species of the genus Leporinus Agassiz (Characiformes: Anostomidae) from the rio Curuá, rio Xingu basin, Serra do Cachimbo, Brazil, with comments on Leporinus reticulatus. Neotropical Ichthyology, 7: $1-10$.

Birindelli, J. L. O., L. M. Sousa, A. Netto-Ferreira, N. Lujan \& M. H. Sabaj-Pérez. 2009. The Pipe Expedition: Relatos da Expedição à Serra do Cachimbo. Boletim da Sociedade Brasileira de Ictiologia, 95: 10-15.

Birindelli, J. L. O., A. M. Zanata, L. M. Sousa \& A. L. NettoFerreira. 2009. New species of Jupiaba Zanata (Characiformes: Characidae) from Serra do Cachimbo, with comments on the endemism of upper rio Curuá, rio Xingu basin, Brazil. Neotropical Ichthyology, 7: 11-18.

Eigenmann, C. H. \& W. R. Allen. 1942. Fishes of western South America. I. The Intercordilleran and Amazonian lowlands of Peru. II. The high pampas of Peru, Bolivia and northern Chile. University of Kentucky, Lexington, 494p.

Eschmeyer, W. N. \& R. Fricke. 2012. Catalog of Fishes electronic version (28 feb 2012). http://research.calacademy.org/research/ ichthyology/catalog/fishcatmain.asp

Fink, W. L. \& S. H. Weitzman. 1974. The so-called cheirodontin fishes of Central America with description of two new species (Pisces, Characidae). Smithsonian Contributions to Zoology, 172: 1-46. 
Freihofer, W. F. 1978. Cranial nerves of a percoid fish Polycentrus schomburgkii (family Nandidae), a contribution to the morphology and classification of the order Perciformes. Occasional Papers of the California Academy of Sciences, 128: 1-78.

Géry, J. 1977. Characoids of the world. New Jersey, T. F. H. Publications, Inc., 672p.

Géry, J. \& A. Zarske. 2002. Derhamia hoffmannorum gen. et sp. n.- A new pencil fish (Teleostei, Characiformes, Lebiasinidae), endemic from the Mazaruni River in Guyana. Zoologische Abhandlungen, 52: 35-47.

Goulding, M., R. Barthem \& E. Ferreira. 2003. The Smithsonian atlas of the Amazon. Washington, Smithsonian Books, 253p.

Lima, F. C. T. \& J. L. O. Birindelli. 2006. Moenkhausia petymbuaba, a new species of characid from the Serra do Cachimbo, Rio Xingu basin, Brazil (Characiformes: Characidae). Ichthyological Exploration of Freshwaters, 17: 53-58.

Machado-Allison, A. 1974. Etapas del desarrollo del pez Piabucina pleurotaenia Regan 1903 (Characiformes: Lebiasinidae). Acta BiológicaVenezoelana, 8: 579-622.

Meinken, H. 1936. Über einige in letzter Zeit eingeführte Fische. Blätter für Aquärien und Terrarkunde, 47: 49-51.

Menezes, N. A. \& S. H. Weitzman. 1990. Two new species of Mimagoniates (Teleostei: Characidae: Glandulocaudinae), their phylogeny and biogeography and a key to the gladulocaudin fishes of Brazil and Paraguay. Proceedings of the Biological Society of Washington, 102: 380-426.

Netto-Ferreira, A. L., O. T. Oyakawa, J. Zuanon \& J. C. Nolasco. 2011. Lebiasina yepezi, a new Lebiasininae (Characiformes: Lebiasinidae) from the Serra Parima-Tapirapecó mountains. Neotropical Ichthyology, 9: 767-775.

Netto-Ferreira, A. L. \& R. P. Vari. 2011. New species of Steindachnerina (Characiformes: Curimatidae) from the Rio Tapajós, Brazil, and review of the genus in the Rio Tapajós and Rio Xingu basins. Copeia, 2011: 523-529.

Sabaj Pérez, M. H. 2009. PIPE-Expedition in die Serra do Cachimbo. Amazonas, 25: 36-43.
Sousa, L. M., A. L. Netto-Ferreira \& J. L. O. Birindelli, 2010. Two new species of Moenkhausia Eigenmann (Characiformes: Characidae) from Serra do Cachimbo, Pará, Northern Brazil. Neotropical Ichthyology, 8: 255-264.

Taylor, R. \& C. C. van Dyke. 1985. Revised procedures for staining and clearing small fishes and other vertebrates for bone and cartilage study. Cybium, 9: 107-119.

Travassos, H. 1960. Notas ictiológicas. X. “Astyanax saltor” sp. n., do estado do Pará, Brasil (Actinopterygii, Cypriniformes, Characoidei). Revista Brasileira de Biologia, 20: 17-20.

Travassos, H. 1964. Sobre alguns peixes do Estado do Pará, Brasil. Anais da Academia Brasileira de Ciências, 36: 539-548.

Vari, R. P. 1995. The Neotropical fish family Ctenoluciidae (Teleostei: Ostariophysi: Characiformes): supra and intrafamilial phylogenetic relationships, with a revisionary study. Smithsonian Contributions to Zoology, 564: 1-97.

Vari, R. P. \& H. Ortega, 2000. Attonitus, a new genus of sexually dimorphic characiforms (Ostariophysi: Characidae) from western Amazonia; a phylogenetic definition and description of three new species. Ichthyological Exploration of Freshwaters, 11: 113-140.

Weitzman, S. H. 1966. Review of South American characid fishes of the subtribe Nannostomina. Proceedings of the United States National Museum, 119: 1-56.

Weitzman, S. H., N. A. Menezes, H.- G. Evers \& J. R. Burns. 2005. Putative relationships among inseminating and externally fertilizing characids, with a description of a new genus and species of Brazilian inseminating fish bearing an anal-fin gland in males (Characiformes: Characidae). Neotropical Ichthyology, 3: 329-360.

Weitzman, M. \& S. H. Weitzman, 2003. Family Lebiasinidae. Pp. 241-250. In: Reis, R. E., S. O. Kullander \& C. J. Ferraris, Jr. (Eds.). Check List of freshwater fishes of South and Central America. Edipucrs, Porto Alegre, 729p.

Zanata, A. M. \& R. P. Vari. 2005. The family Alestidae (Ostariophysi, Characiformes): a phylogenetic analysis of a trans-Atlantic clade. Zoological Journal of the Linnean Society, 145: 1-144.

Submitted November 11, 2011

Accepted June 20, 2012

Published September 28, 2012 